Tempo Social; Rev. Sociol. USP, S. Paulo, 13(1): 67-80, maio de 2001.

\title{
Radicalismos, violências e integração política na Turquia
}

HAMIT BOZARSIAN

RESUMO: Este artigo analisa os principais obstáculos a serem enfrentados para a integração política na Turquia. Mostra que o radicalismo e a violência originam-se em três fontes: a oposição curdo-turca; a oposição alevita-sunita e o avanço do islamismo político, com sua recusa de abandonar a referência religiosa. Contribuíram para a atual fragmentação política as contradições da doutrina kemalista, na qual ainda se assenta a legitimidade do Estado turco; os sucessivos golpes militares de Estado, que obrigam a constantes realinhamentos das formações partidárias; e a militarização de vastas regiões da Turquia em resposta às sucessivas ondas curdas e alevitas de contestação violenta, conduzindo à autonomização dos grupos armados que tendem a perpetuar a contestação e a repressão violentas. Diante desse quadro, o futuro da Turquia depende, por um lado, da integração social das identificações e convicções (curdas, alevitas e islamitas) pelo reconhecimento das culturas regionais e, por outro lado, da adoção do princípio de não-politização das convicções religiosas e do abandono do conservadorismo social por oposição à ocidentalidade.

\section{Introdução}

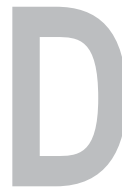

ois aspectos contraditórios distinguem o sistema político turco dos outros do Oriente médio.

Por um lado, esse sistema provou, a partir da passagem ao pluripartidarismo em 1946, sua capacidade de integrar os múltiplos atores políticos. Dezenas de partidos vieram à luz a partir de então e puderam, em
PALAVRAS-CHAVE;

Turquia, política, cultura, violência.

Pesquisador do Centre d'Analyses et d'Interventions Sociologiques (CADIS), da Maison des Sciences de I'Homme, Paris, França 
diversas circunstâncias, participar do exercício efetivo do poder. Por outro lado, entretanto, a essa capacidade respondem uma maior rigidez do establishment e da cultura política, assim como a constância da coerção estatal e da contestação violenta.

Algumas referências históricas serão suficientes para ilustrar esses aspectos: se o regime recorreu pouco à coerção contra seus oponentes políticos, ele impôs, entretanto, um monopólio total sobre o sistema político de 1923 a 1946. Do mesmo modo, se sua visão supra-social do político não o põe ao abrigo de compromissos com certas tribos e confrarias, ele não deixou de gerir menos o social pelo recurso à violência. As revoltas curdas - mas também outras contestações - foram brutalmente reprimidas. O multipartidarismo que conduziu o partido democrata de Menderes e de Bayar ao poder conheceu uma primeira ruptura brutal com o golpe de estado de 27 de maio de 1960. O período de 1960 a 1970 foi marcado pela emergência de novos partidos políticos, mas também por um forte aumento da contestação social, da violência política e pelo golpe de estado de 12 de março de 1971. O período de 1975-1980 testemunharia uma vaga de violência civil, que fez mais de 6.000 mortos. Ela conduziu a um novo golpe de estado, aquele de 12 de setembro de 1980, cujo balanço em termos de violações dos direitos humanos foi desastroso - cerca de 50 execuções, várias centenas de vítimas. Enfim, a passagem ao governo civil em 1983 foi acompanhada da guerrilha do PKK lançada em 1984 (30.000 mortos desde então). Como resposta a essa guerrilha, o poder militarizou a região curda, concentrando nela parte importante das forças armadas e recrutando perto de 70.000 curdos, essencialmente tribais. Paralelamente à guerrilha, assiste-se há uma dezena de anos também a um crescimento do islamismo político, da contestação alevita, da extrema direita de métodos brutais. No curso das décadas de 80 e 90 , os militares continuaram a exercer uma pressão constante sobre a vida política e social do país.

\section{Três épocas da contestação violenta na Turquia}

Essas vagas de contestação e de violência não são certamente independentes entre si. Não se pode, entretanto, analisá-las sob uma perspectiva linear e causalista. Com efeito, cada época está determinada por atores e desafios sociais, políticos e comunitários que lhe são próprios.

Os movimentos sociais dos anos 1960 formulam essencialmente reivindicações econômicas e políticas e recorrem a temas mobilizadores fortes como o "antiimperialismo" e o "antiamericanismo". A contestação desse decênio visa, por um lado, obter a independência da Turquia considerada como um país "semicolonizado" pelo Ocidente e pelo "imperialismo" americano, por outro lado, transformar gradualmente a Turquia em um país de "justiça" social e econômica. A combinação dos dois registros, do nacionalismo e do socialismo, permitiu-lhe assegurar uma larga base social. Os estudantes de esquerda e os sindicatos operários, que ganham uma importância sem precedentes em um país agita- 
do por rápidas transformações econômicas, são o ferro das lanças da contestação. Contestação que tem natureza horizontal por suas reivindicações e modos de ação. Mas os alevitas, que viram com maus olhos o recurso, pelos partidos políticos, à referência religiosa, e os curdos, que encontraram no engajamento socialista e no "antiimperialismo" uma alavanca para renegociar as relações turco-curdas, constituem de fato os seus viveiros sociológicos. Face a essa contestação, a direita radical truculenta do coronel Turkes avança amplamente na região sunita da Anatólia central, para erigir-se em defensora do estado e da "nação" contra o "comunismo". Os enfrentamentos entre seus militantes e os estudantes de esquerda tornam-se mortíferos perto do fim da década 60, legitimando assim o golpe de estado de 1971.

A violência política e civil dos anos 70 obedece, por sua vez, a uma lógica de fragmentação e de comunitarização mais pronunciadas do tecido social. Seus protagonistas definem-se em termos de esquerda e de direita - a extrema direita do coronel Turkes e várias dezenas de grupos de esquerda. Essa violência reproduz com efeito, num grau infinitamente mais elevado, notadamente no meio estudantil, a violência dos anos 60. Mas a "generalização" da violência por toda a Turquia e sua amplitude explicam-se pela autonomização das dinâmicas provinciais, o agravamento das tensões intercomunitárias curdo-turcas e alevita-sunitas e, enfim, sua reprodução, pelo êxodo rural nas grandes metrópoles turcas. Assim, a violência sai dos quadros das universidades para ganhar os colégios, os subúrbios de Istambul, as províncias, onde ela ganha a forma de pogrons. Ela faz mais de 6000 vítimas antes de esgotar-se com o golpe de estado militar de 12 de setembro de 1980.

Os anos 1980-1990 são muito claramente marcados pelos conflitos comunitários e pela radicalização do nacionalismo curdo, mesmo se a violência política propriamente dita não esteve ausente, como testemunham os enfrentamentos nas universidades. Essas violências (mais de 30.000 mortos na guerra do Curdistão, várias centenas em outros lugares) inserem-se agora essencialmente nos dois registros/clivagens: curdo-turco, alevita-sunita. A fragmentação social significa, entretanto, também a fragmentação da própria violência, com o desaparecimento quase total da violência horizontal, tal como ela existia no curso dos anos 60-70: a violência desarticula-se, com efeito, dos projetos políticos concernentes à Turquia em sua totalidade, para não corresponder, de agora em diante, senão à contestação ou à ação de tal ou qual segmento da sociedade.

\section{O islamismo político: contestação e fragmentação}

Com efeito, quando a violência se faz "setorial", "vertical", o islã político representa a única contestação a ter uma aparência de contestação horizontal. Deixando de lado alguns casos raros (assassinatos marcados cometidos por movimentos de pequenos grupos ou hezbollahas curdos), essa contestação não é violenta, mesmo se ela veicula um discurso e uma simbologia 
${ }^{1}$ Utilizo esse termo não no sentido antropológico, mas etimológico.

2 As tentativas do Refah de dotar-se de uma clientela alevita fracassaram amplamente. Além disso, a nomeação por Erbakan de Sevtek Kazan, advogado dos autores do assassinato de 37 intelectuais, em sua grande maioria alevitas, em 1993, como ministro da Justiça foi considerada como uma manifestação de hostilidade.

Estes são os termos utilizados em um comunicado militar que data de 6 de julho de 1998 . radicais. Quando ela tem os meios de integrar-se ao sistema político, pode mostrar-se, sobre assuntos sensíveis como a questão curda ou os direitos humanos, tão estatista quanto o exército ou o establishment. Essas margens de manobra são, entretanto, estreitas:

1. Emanando, em virtude de seu programa político e de sua base sociológica, do sunismo, poderoso no seio das populações sunitas marginalizadas ou das classes médias das grandes metrópoles, o islamismo inscreve-se numa lógica segmentária ${ }^{1}$ e exclui o alevismo ${ }^{2}$. Ele é igualmente, por razões que não poderei detalhar aqui (cf. Bozarsian, 1996), definido por essa última comunidade como a principal ameaça contra ela. A experiência governamental do Refah, de 1996 a 1997, acentuou a desconfiança - de fato justificada - dessa comunidade com relação ao islamismo. Assim, "horizontal" em virtude de suas reivindicações e de seus projetos políticos, sociais e culturais, o islamismo torna-se vertical em sua organização e funcionamento, acelerando a fragmentação do tecido social. Ao fazer isso, ele estreita volens nolens sua base social.

2. Em virtude de sua ascensão, ou de sua simples existência, o islamismo aporta um trunfo maior ao exército: combatê-lo e defender pelo mesmo motivo o "kemalismo" e seu objetivo de "alcançar a civilização contemporânea", de "defender a revolução kemalista contra a reação" 3 torna-se uma, se não for $a$ missão do exército, erigindo-o novamente em ator-árbitro da vida política turca. Assim, as pressões que os militares exerceram sobre o Refah tornaram curta a experiência do governo de Necmeddin Erbakan, derrubado por um ultimatum. Essa queda programada não foi suficiente para fazer o islamismo turco cair na violência, mas ela constituiu, para muitos militantes, a prova material da impossibilidade de um combate legal. Além disso, as pressões militares não pararam após a queda de Erbakan, nem mesmo após a interdição de seu partido em 1998: elas continuaram num ritmo acelerado durante a totalidade dos anos 1997 e 1998, dando com isso um sinal claro aos islamitas: o exército não aceitará qualquer compromisso e não considerará a guerra como terminada senão quando os islamitas forem massacrados.

3. Enfim, o que não surpreenderá a ninguém, é sobre o fundo da ascensão do islamismo que se nutre a aliança entre a intelligentsia (redatores e editores de jornais, uma parte importante do corpo de professores, principalmente nas universidades, artistas...) e o exército. Essa aliança é ao mesmo tempo contra a natureza e "normal". Contra a natureza, tendo em vista o sofrimento e a humilhação que os militares infligiram aos intelectuais nos golpes de estado do passado, mas "natural", se se leva em consideração os temores da intelligentsia e seu engajamento neo-kemalista. Ela soa igualmente a ruptura entre os islamitas e os intelectuais ditos kemalistas ou de esquerda, provocando assim novas linhas de divisão. Assim, a equação "islamitasecularista", - equação que resistirá mal à mais simples prova empírica -, não deixa de ser menos uma das clivagens cruciais da sociedade turca: se no seio do exército, o "Grupo de Estudo - Ocidente" (Bati Çalisma Grubu), sob a 
responsabilidade direta de Çevik Bir, candidato ao posto de chefe do estadomaior interarmas, encarrega-se de fornecer as bases doutrinais da ofensiva contra os islamitas; no seio da intelligentsia, ouvem-se já vozes reivindicando uma "guerra total contra os islamitas" a fim de "evitar"... uma inelutável guerra civil. Para a oposição islamita essa evolução não constitui senão uma nova etapa da "traição secular ${ }^{4}$ dos intelectuais" contra sua "cultura" e sua "civilização", mas também - argumento novo - contra a democracia. Assim, "democratas", quando se trata de suas próprias liberdades de expressão, os "intelectuais" tornar-se-iam repressivos, aliados da coerção, quando se trata das escolhas que os eleitores formulam pela via democrática.

\section{As fontes dos radicalismos e da violência na Turquia}

É naturalmente impossível fazer prognósticos sobre o futuro das contestações radicais e das violências na Turquia. Três fatos são, entretanto, suscetíveis de pesar sobre as configurações futuras.

Em primeiro lugar, a despeito do enfraquecimento do PKK, a violência na região curda não está pronta para cessar. A rigidez da política oficial - nenhuma medida concreta, mesmo no plano do reconhecimento dos direitos culturais, foi tomada a respeito - constitui uma fonte de novos radicalismos. Mais importante talvez seja o fato de que nem o estado nem o PKK chegam agora a controlar as dinâmicas locais, amplamente militarizadas e autonomizadas.

Em segundo lugar, os sinais de passagem à violência da contestação alevita multiplicam-se, mesmo se ela se legitima em termos "universalistas", "marxista-leninistas". Com efeito, a imprensa relata - agora intensamente - as atividades da guerrilha em regiões tão vastas como a Anatólia central e às margens do Mar negro. Antes de ser a "infiltração" do PKK, que estaria "desfeita" na região curda, essas atividades são, na realidade, obra dos grupos “marxista-leninistas" - Dev, Sol, TKP, ML - poderosos quase que exclusivamente no grupo alevita. O alargamento do campo de atividade das "equipes especiais" da polícia e a constituição das brigadas dos "Protetores de cidades" nessas regiões constituem uma etapa decisiva na militarização das clivagens comunitárias nessas regiões.

Enfim, os riscos de passagem à violência do Islã político, cuja integração no sistema conheceu uma interrupção brutal, não devem ser negligenciados. As tentativas de paralisar os antigos dirigentes do Refah pela interdição dos direitos civis e os novos dirigentes, como Erdogan, prefeito de Istambul, ou o presidente da MUSIAD (Associação dos homens de negócios muçulmanos), por penas de prisão, terão inelutavelmente como conseqüência a fragmentação da oposição islamita em agrupamentos autônomos e potencialmente radicais.

Como fazer então para que o sistema político turco tenha a capacidade de integrar essas oposições, que se distinguem radicalmente das opo-
4 A tradição islamita fixa o começo dessa "traição" nas reformas de Tanzimat (1838). 
BOZARSIAN, Hamit. Radicalismos, violências e integração política na Turquia. Tempo Social; Rev. Sociol. USP, S. Paulo, 13(1): 67-80, maio de 2001.

${ }^{5}$ Com efeito, tomado no sentido metafísico do termo (a expressão é de Parla, 1989), tal como o impõe a Constituição, o kemalismo é suscetível de justificar qualquer tipo de prática do poder (pluralismo político e democracia, ditadura militar, comunismo, fascismo, sistema teocrático). A razão é que os versículos kemalistas constantemente reeditados por diferentes ministérios são contraditórios. Eles não constituem um corpo de recomendações pronunciadas em abstrato, mas inscrevem-se em contextos históricos particulares, o que impede toda tentativa de erigí-los em um dogma. Não é, portanto, surpreendente que um homem como Turgut Özal, cujo programa político reduzia-se a enterrar o kemalismo, tenha podido proclamar-se kemalista, ou que um partido tão pouco kemalista como o Refah pudesse tirar vantagem do kemalismo ("se ele estivesse vivo, teria aderido a nosso partido") e, enfim, que, apoiados na abundante correspondência de Mustafa Kemal, certos atores curdos possam, com um prazer malicioso, tentar dar uma legalidade à "igualdade curdo-turca" e colocar seus juízes, dotados sições conservadoras e social-democratas do passado, seja por seus traços sociológicos - crescendo cada vez em um segmento da população que não se reconhece em um conjunto político -, seja por suas reivindicações, discursos e simbolismo? É evidente que, tendo em vista os fundamentos do sistema político turco, a integração dessas contestações põe problemas tão complexos quanto, por exemplo, aquele das oposições horizontais - socialista no Marrocos, islamita no Egito. Ela não se constitui menos na condição para a pacificação do espaço político.

\section{O kemalismo, o exército e a fragmentação do sistema político}

Para responder a essa questão, convém de início insistir nos obstáculos a essa integração, a começar por um fator "cinza" hipotecado pelo futuro do sistema político.

Esse fator é o kemalismo, ou o neo-kemalismo, que tem como corolários a laicidade, a "contemporanização" - ou, dito de outro modo, a ocidentalização - e o nacionalismo turco. Esse "kemalismo", tal como ele se erigiu em doutrina oficial e como condição do contrato de cidadania pela Constituição, não tem de fato senão poucas relações com o kemalismo como doutrina e prática do poder da Turquia dos anos 1923-1946. Fortemente impregnado pela herança de União e Progresso (1908-1918) e pelas experiências do período entre as duas guerras - União soviética, Itália, Alemanha -, o kemalismo de Kemal Atarürk era uma doutrina de partido e chefe únicos, de estatismo tanto político como econômico, de um nacionalismo inicialmente cultural e depois, nos anos 30 , claramente etnicista ${ }^{5}$. Não é necessário analisar aqui o deslizamento dessa doutrina e dessas práticas de poder para o kemalismo dos anos 60-90. É suficiente precisar que com as idéias de esquerda em voga nesses anos, o kemalismo forneceu à intelligentsia uma legitimação de sua ação militante e de sua contestação do poder, antes de transformar-se em uma doutrina da legitimação do establishment militar e civil. O kemalismo é socialmente anacrônico como o mostram amplamente o nacionalismo curdo, a efervescência islamita, o constante recurso do estado à referência religiosa. Tampouco tem o kemalismo a capacidade de assegurar uma mobilização social (os partidos kemalistas são inexistentes e as manifestações kemalistas conseguem a duras penas mobilizar algumas centenas de pessoas). Ele não constitui, tampouco, o universo mental da intelligentsia "ocidentalizada" e sobretudo dos oficiais, cuja formação está baseada num espírito de "fortaleza ameaçada do interior e do exterior". Ele erige igualmente o exército como garantia do sistema no interior e dota-o do estatuto de ator supra-social e extra-parlamentar do sistema político. Nessa atribuição, o exército é amplamente assistido pelo poder judicial, a Corte constitucional e as Cortes de Segurança do estado.

Em vista desse conjunto de razões, essa doutrina oficial é de fato a doutrina do establishment. Ela constitui-se, contudo, em um dos obstáculos 
BOZARSIAN, Hamit. Radicalismos, violências e integração política na Turquia. Tempo Social; Rev. Sociol. USP, S. Paulo, 13(1): 67-80, maio de 2001.

maiores à evolução do sistema político, porque ela constitui o universo mental de gerações de oficiais e de corpos de professores e porque ela alarga o campo de manobra do exército, legitimando-o em seu papel constitucional de "garantidor da ordem no interior", de "guardião do kemalismo" e da "laicidade".

Todavia, a legitimidade doutrinal e constitucional não é a única a justificar o lugar do exército na vida política turca. Com efeito, o exército encontra-se face a um sistema político fragmentado, dividido em partidos políticos concorrentes, incapazes de constituir coalizões de poder e de oposição fortes. Essa fragmentação, que não foi objeto de um estudo sério, não é, sem dúvida, unicamente o fruto da herança dos golpes de estado que subverteram os equilíbrios políticos tradicionais do país nem, menos ainda, exclusivamente o fruto da competição pessoal dos dirigentes dos partidos ${ }^{6}$. Tudo indica que ela traduz tendências em direção à atomização e às recomposições dos grupos sociais, com a acentuação dos interesses políticos e dos clientelismos segmentários tanto no nível das províncias, como da nação. Ela é, em todo caso, a imagem da complexidade e da heterogeneidade sociais do país. Segue-se também que ela tem como consequiência a emergência de legislativos fracos, isolados, incapazes de formar maiorias suscetíveis de empreender um braço de ferro com o exército e a Corte constitucional, para levar a cabo as reformas que são desejadas individualmente por numerosos políticos, principalmente na gestão das administrações locais, da questão curda e do islã político.

A palavra de ordem do "pragmatismo", que se resume de fato a "compor" com o exército e com o órgão extra-legislativo, que é o Conselho Nacional de Segurança, não pode então constituir mais que um obstáculo maior para a classe política em seu conjunto. Ela traz no seu rastro uma perda de crédito e de prestígio: assim, as coalizões dirigidas por Demirel e Çiller (1991 e 1995) simplesmente avalizaram as decisões tomadas pelo Conselho Nacional de Segurança. Aconteceu o mesmo com o governo de Erbakan (1996-1997) que foi obrigado a assinar, entre outros, o programa de luta "anti-reacionária" (irtica) - ou seja, o programa que visava a desmantelar seu próprio partido. A coalizão heteróclita dirigida por Yilmaz - que reagrupava um partido conservador, um partido originário da cisão do DYP de Çiller, e um partido social-democrata sustentado por um segundo partido social-democrata que não participava do governo - também teve que passar por essas composições humilhantes, ao preço de ser percebida pela opinião pública turca como um simples cartório do Conselho Nacional de Segurança.

Assim, o sistema político turco enfrenta uma dupla crise de legitimidade: a da doutrina oficial que provoca as contestações curda, alevita e islamita; a do sistema político que se concretiza em seu imobilismo e sua instrumentalização de fato pelo exército, acarretando a sua perda de credibilidade no seio da sociedade. de outros versículos, em posição delicada. Enquanto tal, o kemalismo não pode evidentemente constituir-se em um objeto de pesquisa, muito menos em uma base jurídica viável. Em uma tal abordagem, o pesquisador poderia interessar-se, quando muito, pelo culto que lhe é dedicado e por seu lugar no imaginário popular e burocrático. Se adotar-se, ao contrário, um método que historize o kemalismo como doutrina e prática do poder, assim como sistema jurídico elaborado nos anos 30 (reformas no domínio religioso, seis flechas do Partido único, fusão do Partido e do Estado, nacionalismo antropológico, culto do "chefe eterno", rejeição do passado otomano, instrumentalização da religião conjuntamente com uma política agressiva nessa questão, etc...), concluir-se-á naturalmente que ele existiu completamente. Mas, nessa perspectiva, seria preciso inevitavelmente admitir que, como a maior parte das experiências de partidos-únicos do entre-guerras, ele está também completamente morto; e isso, desde a passagem ao pluralismo político em 1945. Algumas das reformas de Mustafa Kemal, que se inscre- 


\section{O fenômeno dos grupos armados}

vem na linhagem dos movimentos de secularização do Império otomano, conheceram sem dúvida uma posteridade real, mas não os elementos que singularizaram seu regime. Ninguém pode, desde então, pretender um sistema político, no qual "só o chefe da sociedade humana é digno de ser santificado". Do mesmo modo, não há político algum que ousaria fazer a apologia do estatismo, ou medir os tamanhos dos crânios e dos ossos para provar a superioridade racial dos turcos, propor a fusão do Estado com um partido, nomear deputados ou obrigar os professores de história a reconhecer sua "ignorância" em torno de uma mesa coberta de bebidas alcoólicas... Por outro lado, a estrita conformidade com o kemalismo (e com a letra da Constituição) resultaria de jure na interdição de todas as formações, com exceção do MHP.

${ }^{6}$ Com efeito, os golpes de estado de 1960 e de 1980, ao interditar certos partidos ou seu conjunto, deram um duro golpe no conjunto do sistema político. Os partidos não puderam inscrever-se na duração, preservar suas bases e, sobretudo, agir em um espaço juridicamente protegido. Assim, o golpe
Esses obstáculos estruturais são reforçados por um fenômeno que é o correspondente da fragmentação da classe política: a emergência dos "grupos" ditos "uniformizados". Com efeito, se o exército e a polícia - os efetivos desta última foram consideravelmente reforçados pela constituição de "equipes especiais" nos anos $1990^{7}$ - mantêm-se eficazes enquanto forças de coerção, não acontece o mesmo no que concerne a sua função enquanto corpo de solidariedade e de coesão. Incapaz, já nos anos 70, de controlar seu aparelho burocrático ou de impor sua autoridade na escala provincial (cf. Bozarsian, 1997), o estado - assim como o sistema político - conheceu igualmente uma fragmentação interna nos anos 80-90. A multiplicação dos serviços de informação ${ }^{8}$ e a constituição de milícias civis (nas regiões curdas, mas também "mistas" alevita-sunitas) aumentaram o número de corpos em posse de armas. Assim também, desejoso de não implicar diretamente os serviços da ordem nas execuções extrajudiciais dos "homens de negócios" curdos próPKK e dos intelectuais de oposição, em sua maioria curdos, o estado recorreu amplamente, depois de 1993, aos serviços de antigos militantes da extremadireita, dentre os quais alguns foram ou são procurados pela Interpol por cerca de duas décadas ${ }^{9}$. Ao fio dos anos, essas equipes especiais, serviços de informação e militantes de extrema-direita, compartilhando seu espírito de corpo, suas armas e o "dever de sangue" que eles realizam pela "nação", puderam autonomizar-se, articular-se com a máfia para tomar parte no tráfico de drogas - cerca de 25 bilhões de dólares por ano - e sobretudo conduzir uma guerra interna particularmente sangrenta. Se nenhum desses grupos tem interesse em enfraquecer o estado - todos têm o interesse de investi-lo e de utilizálo a seu próprio favor -, não é menos verdade que sua relação de subordinação original evoluiu: o estado, após estar na posição de demandante de sua força de ataque, parece ter-se agora tornado um simples provedor de fundos, o objeto de seu assalto e a caução de sua imunidade.

Essa fragmentação tem três conseqüências importantes para nosso assunto. A primeira concerne à política de erradicação pela destruição sistemática das cidades curdas e pelas execuções extrajudiciais, cujas vítimas contam-se aos milhares. Essas práticas apresentadas como os imperativos militares da luta contra o PKK estão, de fato, ligadas à ampliação do campo de manobra dos diferentes atores implicados na guerra curda e na violência. A perpetuação da guerra impõe-se, com efeito, como uma fonte de renda securitária quase inesgotável. Se é a guerra que justificou no passado o aparecimento desses atores, é a renda que ela proporciona e a competição interna para obter dela o maior benefício que explicam a sua continuidade. A ampliação desse campo de manobra significa igualmente que os atores da segurança dispõem de alianças tanto no seio da população, principalmente tribal, como no seio do poder militar e policial - com o consentimento do Conselho Nacional de Segurança e de Mehmet Agar, ex-diretor da Polícia, ex-ministro do 
BOZARSIAN, Hamit. Radicalismos, violências e integração política na Turquia. Tempo Social; Rev. Sociol. USP, S. Paulo, 13(1): 67-80, maio de 2001.

interior -, e no seio dos partidos políticos, como mostraram as reincidências do caso de Susurluk ${ }^{10}$. A segunda consequiência, que decorre da primeira, concerne às lutas de influência e, sobretudo, aos sangrentos ajustes de contas no seio dos serviços secretos - generais e agentes de informação seqüestrados, torturados, assassinados ${ }^{11}$. As conexões desses serviços no coração do estado e seu super-armamento fazem de seu eventual desmantelamento uma tarefa imperativa, mas também delicada, que não pode ser feita senão ao preço de medidas coercitivas, cujas conseqüências são imprevisíveis.

Enfim, deve-se temer que esses bandos, agora amplamente autonomizados, sejam tentados a levar a seu paroxismo toda nova tensão social - um braço de ferro mais brutal com os islamitas ou a radicalização da contestação alevita -, para financiar assim novamente imperativos securitários pela perpetuação da renda guerreira ${ }^{12}$. Esse aspecto econômico não é, entretanto, o único que deve ser levado em conta: um conflito, principalmente um conflito violento no qual se arrisque cotidianamente a vida, traz igualmente benefícios simbólicos, dando origem a um verdadeiro culto dos grupos aureolados de prestígio.

\section{O imperativo de uma tripla integração}

Enfim, o sistema encontra-se diante da necessidade de integrar os novos atores. Contrariamente a certos países do Oriente médio, na Turquia o termo "integração" não significa mais a ampliação do espaço político às oposições horizontais que vieram à luz, pois as perspectivas de uma tal integração existem desde 1946, e isso apesar dos intermédios militares e dos radicalismos sucessivos. O principal problema do sistema é que os atores sociais e políticos identificam-se cada vez mais com um segmento da população e desenvolvem-se em seu seio, em detrimento dos desafios que dizem respeito à sociedade no seu conjunto. $\mathrm{O}$ desafio consiste conseqüentemente em criar um espaço político horizontal, que fosse legitimado pelo conjunto dos grupos políticos, etnolinguísticos e etno-confessionais; espaço no qual poder-se-ia investir.

Essa transformação não se pode fazer senão pelo reconhecimento de outros espaços, culturais, cultuais e/ou administrativos, independentes das clivagens políticas. É igualmente necessário que esses espaços apropriados, da curdicidade, da turquidade, do islã sunita, do alevismo e, enquanto sistema de crenças quase metafísico, do kemalismo, sejam legitimados pelo conjunto dos atores, sem que a adesão a um entre eles imponha-se como condição da cidadania ou do "fazer político". Esses espaços existem socialmente; mas de fato somente dois entre eles, a turquidade e o kemalismo, são legitimados, posto que pertencer a um ou ao outro é imposto como critério da legalidade jurídica e política. A despolitização desses dois espaços assim como a legitimação, sempre por meio da despolitização mas também da despenalização, dos três outros impõem-se como uma urgência. de estado de 1960 interditou o Partido democrático de Adnan Menderes, executou ou condenou a duras penas de prisão seus dirigentes, com o efeito de dar nascimento a uma direita fragmentada, cujos herdeiros, a começar por S. Demirel, tiveram muito trabalho para juntar as peças. Do mesmo modo, o golpe de estado de 1980 interditou os partidos políticos existentes e encorajou a formação de três novos partidos que os militares acreditavam poder controlar. Esses novos partidos aproveitaram de sua situação de "monopólio" para dotar-se de uma clientela eleitoral, aceder às cadeiras parlamentares, sem possuir, entrementes, a legitimidade partidária que aureolava os antigos dirigentes interditados. Estes reemergiram alguns anos mais tarde, reconstruindo suas antigas formações, tentando reconquistar suas bases e, por isso mesmo, contribuindo para a fragmentação. As rivalidades pessoais, o espírito de vingança... foram outros fatores que tornaram agudos os conflitos no seio da classe política.

7 Ditos os "boinas malvas" ou os "ninjas"; eles são em número de 23.000. Mas sua força vem mais do 
BOZARSIAN, Hamit. Radicalismos, violências e integração política na Turquia. Tempo Social; Rev. Sociol. USP, S. Paulo, 13(1): 67-80, maio de 2001.

treino de guerrilha recebido na guerra contra o PKK, de seu espírito de corpo e de seu estatuto privilegiado no seio da polícia que de seu número.

${ }^{8}$ Assim, a MIT (Organização nacional de informação) foi duplicada pela constituição de serviços de informação da guarda nacional, do exército e, enfim, da polícia.

9 Para os documentos cf. Özdemir (1997).

10 Acidente de automóvel onde morreram, no fim de 1996, A. Çatli, militante da direita radical procurado há 18 anos pela Interpol, sua amante, assim como H. Kocadag, um dos chefes da polícia de Istambul. S. Bucak, chefe tribal curdo e deputado do DYP de Çiller, sobreviveu.

${ }^{11}$ Assim, vários generais, entre os quais o chefe do Estado-maior da gendarmaria E. Bitlis, e vários responsáveis pelos serviços secretos, entre os quais C. Ersever e T. Ümit, encontraram a morte entre 1993 e 1997.

12 Aliás uma renda que pode utilizar os mesmos canais que os grupos de oposição. Assim, E. Asik, falando de Tarik Ümit, explicava "sim, ele era nosso homem, mas ao mesmo tempo ele começava a tirar vantagens pessoais do negócio (tráfico) de heroína”. Ele acres-
1. o espaço da curdicidade e do movimento curdo. A legitimação desse espaço, fatualmente existente, pode realizar-se pela legalização das formações curdas e pelo reconhecimento de uma autonomia cultural e/ou administrativa das populações e das regiões curdas ${ }^{13}$. Trata-se, sem dúvida, da integração mais complexa, tanto que ela suscita medos, traumatismos de divisão e de insegurança, bem como sentimentos nacionalistas turcos, ao mesmo tempo em que põe em questão a concepção que a república turca tem da nação. Essa integração é, entretanto, talvez a mais fácil de ser realizada pelo voluntarismo político: com efeito, praticamente o conjunto da classe política, da opinião pública, das organizações profissionais - a começar pelos homens de negócios - e dos intelectuais - compreendidos numerosos intelectuais kemalistas - concorda agora com a impossibilidade de resolver a questão curda com uma vitória militar ou com simples medidas econômicas destinadas a desenvolver a "região do leste ou do sudeste". A despeito do veto dos militares, o terreno parece, portanto, estar pronto para reformas radicais nessa matéria.

Numa perspectiva em que as administrações locais se encarregariam das questões relevantes de seus territórios, como a escolha da língua, a educação, os meios de comunicação, a gestão municipal, uma parte da fiscalização..., as tensões com base no radicalismo curdo poderiam interromper-se, permitindo, assim, a transformação dos partidos curdos legalizados em filiais das formações políticas abertas à escala da Turquia. Isso exigiria igualmente o fim do regime de exceção prevalecente no Curdistão desde o início dos anos 1980, assim como a desmilitarização das dinâmicas tribais pelo desarmamento das brigadas de "Protetores da cidade".

2. O espaço do alevismo. Trata-se, também aqui, de um fundamento - desta vez não escrito - da doutrina oficial, mas também de um paradoxo que a caracteriza. Oficialmente laica, a Turquia kemalista, que se construiu sobre a herança (e as ruínas) da época unionista, não deixou por isso de basear-se menos no islã sunita. Com efeito, na Turquia kemalista, a marginalização do islamismo e, para além, do islã como sistema teológico não é possível senão porque o islã faz parte dos denominadores sociais e políticos da Turquia. A "islamização", concebida como um processo contínuo, é um dos objetivos do nacionalismo turco tal como formulado por Ziya Gökalp (1876-1924), seu pai fundador, e amplamente perpetuado na época kemalista e pós-kemalista. A homogeneização demográfica do país durante e no final da Primeira Guerra mundial fez do islã a religião agora dominante na Turquia. Se a elite kemalista no poder interdita toda iniciativa política, a saber, civil, baseada no islamismo, por vezes até mesmo pretende-se abertamente anti-religiosa, a referência religiosa, monopolizada pelo estado, continua entrementes a constituir uma fonte maior da legitimação do poder e da política (cf. Bozarsian, 1996).

A época pós-kemalista, com a competição partidária que ela engendra entre os partidos políticos, testemunha a amplificação do recurso à referência religiosa pelos partidos políticos (e isso bem antes da ascensão do islã polí- 
BOZARSIAN, Hamit. Radicalismos, violências e integração política na Turquia. Tempo Social; Rev. Sociol. USP, S. Paulo, 13(1): 67-80, maio de 2001.

tico), com as consequiências da marginalização dos alevitas e do aguçamento dos conflitos intercomunitários e das competições comunitárias para aceder aos recursos. Esses aspectos explicam em grande parte a violência dos anos 70 e as radicalizações dos anos 80-90. No curso desses processos, o alevismo, cujas fronteiras confessionais transformaram-se pouco a pouco em fronteiras étnicas, chegou a não mais conceber o espaço político turco como um espaço legítimo. Para a maior parte dessa comunidade, esse espaço não é mais o "deles" mas, com os conflitos internos que o caracterizam, o espaço dos "outros".

Essa rejeição não é unicamente a consequiência de uma reação com respeito à confissão majoritária, mas também com respeito à violência da qual os alevitas foram alvo depois de várias décadas: se os anos 70 foram marcados por verdadeiros programas anti-alevitas, dentre os quais o de Maras ${ }^{14}$, os anos 80-90 foram simbolicamente carregados por cenas de violência. Assim, nas regiões mistas, a saber, alevita-sunitas, o estado assegurou o armamento das populações sunitas. O incêndio de Sivas em 1993, onde morreram 37 intelectuais, alevitas na sua maior parte, os tumultos de Gazi (Istambul) em 1994, onde a repressão policial fez mais de vinte vítimas entre a população civil, e a política de destruição das cidades alevitas que se generalizou nas regiões de Sivas e de Tunceli... são tantos outros fatores que explicam o retorno da comunidade sobre si mesma, seus ressentimentos e seus temores do poder, mas também da classe política em seu conjunto.

A integração do alevismo - e, ulteriormente, a solução do problema confessional na Turquia - põe-se de início em termos da igualdade entre as confissões. Essa igualdade não pode ser obtida senão sob certas condições prévias: a retirada total do estado do campo religioso, o abandono da subordinação das instituições sunitas ao estado e da funcionalização de seu pessoal ${ }^{15}$, assim como a imposição do islã sunita como religião, por falta, do conjunto da sociedade. Isso significa também o abandono da legitimação do poder e da política pela religião ou, dito de outro modo, da instrumentalização da referência religiosa pelo estado e pelos partidos políticos, certamente pelo Refah, mas também por outras formações, tanto de direita como de esquerda ${ }^{16}$. É evidente que essa evolução deveria ser acompanhada de oportunidades reais de igualdade em termos econômicos, políticos e simbólicos. Enfim, é necessário que o estado renuncie a sua visão que identifica o alevismo a uma espécie de siba, ou seja, de sedição ${ }^{17}$.

3. O espaço do islã político. O islamismo aparece seja como principal ator do espaço político seja como desafio ao monopólio do Estado sobre a produção do discurso e do simbolismo oficiais. Toca-se assim em um dos pilares da doutrina oficial e de seu contrário, para não dizer seu impasse: enquanto que a doutrina, inicialmente gökalpista, e a seguir kemalista, faz do islã sunita o denominador por falta da sociedade, ela tenta contrabalançar as conseqüências políticas pelo objetivo de "contemporaneização", ou seja, de ocidentalização. Em outros termos, ao mesmo tempo em que o Estado tenta monopolizar a referência religiosa, ele se fixa o objetivo contrário de reduzir o centava igualmente que Ümit mantinha também ligações com D. Karatas, chefe do Dev-Sol (cf. Özdemir, 1997).

${ }^{13}$ As reformas administrativas que conduzem a uma verdadeira descentralização são de uma importância crucial para as regiões curdas. Mas elas impõem-se igualmente para as outras regiões, pois a gestão centralizadora mostra-se incapaz de fazer frente aos desafios locais. Turgut Özal, presidente da República falecido em 1993, sublinhava a necessidade de tais reformas como elemento central para a solução da questão curda.

${ }_{14}$ Nos massacres perpetrados pela direita radical em Maras em 1979, mais de 100 alevis (as cifras oficiais são nitidamente superiores) morreram.

15 A presidência das Questões religiosas, cujo orçamento ultrapassa em muito aqueles de vários ministérios, não reconhece senão o islã sunita como religião.

${ }^{16}$ Não se deve esquecer que o DSP (Partido da esquerda democrática de B. Ecevit) e os outros partidos de direita têm amplo recurso a essa referência.

${ }^{17}$ A formulação mais completa dessa visão é um documento se- 
creto de 2 de junho de 1980, assinado pelo general Evren, chefe do estado maior, que se tornou alguns meses mais tarde o chefe da junta militar e o interventor da Turquia nos anos 80 e 90. Intitulado "Documento acerca das ameaças internas", esse texto definia os alevitas nos seguintes termos: "os alevitas, que constituem uma comunidade fechada, procuram, parcialmente encorajados nisso por forças externas (ditas gûçler), infiltrar-se nos órgãos do estado nas regiões em que se encontram agrupados a fim de exercer uma influência política. Quando isso não é possível, agem de modo a utilizar os órgãos oficiais municipais para seus próprios interesses, esforçando-se em expulsar os funcionários, os oficiais e os cidadãos que não fazem parte de seu grupo para fora dessas regiões e colaboram com aqueles que empreendem atividades curdistas" (Pehlivan, 1993, p. 188). campo religioso a proporções que ele poderia gerir e monopolizar. Ainda que de facto, embora não de jure, islamita contra o alevismo, o Estado é antiislamita contra um ator islamita. Essa soma de contradições poderia ser gerida em uma sociedade fechada, de recursos limitados, que interdita a competição entre as comunidades e os grupos sociais, e governada por um poder que se concebe em termos supra-sociais como o poder kemalista. Ela torna-se impossível de gerir, quando a competição em torno dos recursos econômicos, políticos e simbólicos causa grande desordem em um período de mobilizações urbanas e de pluripartidarismo. Elevar o islã sunita a denominador comum da sociedade e combater, ao mesmo tempo, o islamismo reduz inevitavelmente a sustentação do Estado tanto no seio dos alevitas como no seio dos sunitas. O Estado arrisca, então, encontrar-se face a dois "inimigos", enfraquecendo assim as bases sociais sobre as quais pode assentar-se.

A integração social do islamismo arrisca, entretanto, ser mais complicada que as duas precedentes e isso, não apenas porque se trata de uma luta pela produção e monopolização dos discursos e dos simbolismos, ou porque o exército encontra agora na "defesa da laicidade" a missão que lhe fazia falta. A razão mais importante é outra: se o objetivo é evitar uma fragmentação ainda mais acelerada da sociedade sobre uma base etnoconfessional, a integração do islamismo deve, ao mesmo tempo, chegar à despolitização da referência religiosa. Com efeito, o paradoxo é que, para tornar-se uma força realmente horizontal, representativa das diversas camadas da sociedade, o islamismo deveria renunciar a ser turco a fim de englobar os curdos e não mais apresentar-se unicamente como sunita, para incluir em termos de um programa político os alevitas que pudessem reconhecer-se nele. Na hipótese contrária, ele não pode ser considerado senão como o representante ou o poder dos sunitas contra os alevitas. É claro que para isso o islamismo deve renunciar àquilo que faz sua especificidade, ou seja, a ser islamita, o que significa seu naufrágio.

\section{Conclusão}

Assim, o sistema político turco encontra-se confrontado a uma dupla exigência:

1. Integrar socialmente as três fontes de contestação, mas sem provocar conflitos de incompatibilidade, ou seja, fazer aceitar o espaço de cada uma delas ao conjunto da sociedade como base e condição de um contrato social.

2. Fazer admitir, ao mesmo tempo, o princípio da não-politização dessas pertinências e convicções (curdicidade por oposição à turquidade; alevismo por oposição ao islã sunita, islamismo como forma de religiosidade social e, para além disso, como conservadorismo social, por oposição à ocidentalidade).

A opinião pública parece estar pronta para tais soluções. Como prova, já faz um decênio que os debates em torno de uma Segunda República ressurgiram esporadicamente na Turquia, principalmente no momento de cri- 
BOZARSIAN, Hamit. Radicalismos, violências e integração política na Turquia. Tempo Social; Rev. Sociol. USP, S. Paulo, 13(1): 67-80, maio de 2001.

ses agudas. Uma "Segunda República”, que se seguiria à primeira, que se tornou obsoleta, mas que continua a existir como fonte da instabilidade política, dos radicalismos e das vagas de violência. Uma segunda república que relegaria a primeira seja ao domínio das convicções e das memórias coletivas despolitizadas, seja, enfim, àquele de objeto de estudos históricos e não mais fonte de conflitos e legitimações das configurações atuais.

É evidente que o caminho que poderá conduzir a isso é estreito, os riscos de derrapagem múltiplos. As chances da Turquia não passam por isso menos por essas recomposições.

Recebido para publicação em novembro/2000

Tradução de Pablo Rubén Mariconda

BOZARSIAN, Hamit. Radicalisms, violence and political integration in Turkey. Tempo Social; Rev. Sociol. USP, S. Paulo, 13(1): 67-80, May 2001.

ABSTRACT: This article analyses the main obstacles to be faced for the political integration in Turkey. It shows that radicalism and violence spring from three sources; the Turkish-Kurd opposition; the Sunite-Alevite opposition and the rise of political Islamism, with its refusal to abandon religious reference. What has contributed to the present political fragmentation are the contradictions of the Kemalist doctrine, on which the legitimacy of the Turkish State is based; the successive military coups d'etat that cause constant party realignements; and the militarization of vast regions of Turkey to hold back the successive waves of Kurdish and Alevite violent uprisings, which, in turn, give autonomy to armed groups that tend to perpetuate the violent contends and repression. From this perspective, the future of Turkey depends, on the one hand, on the social integration of identifications and convictions (Kurds, Alevites and Islamites) for the recognition of regional cultures and, on the other, on the adoption of the principle of non-politization of religious convictions and the abandonment of social conservatism as an opposition to westernization.

\section{REFERÊNCIAS BIBLIOGRÁFICAS}

BozArSIAn, Hamit. (1996) Boire la coupe jusqu'à la lie. Le Parti de la Prospérité en Turquie. Les travaux du Centre Marc Bloch, (8): 5-46. 
(1997) Chaos ou mutations sociales: Notes sur la crise turque des années 70. Cultures et Conflits, (25): 79-98.

ÖZDEMIR, Veli. (1997) Susurluk Belgeleri. 2 vols. Istambul, Scala .

PARla, T. (1989) Turkiye’de Anaysalar. Istambul, Iletisim.

Pehlivan, Battal. (1993) Alevilik ve Diyanet. Istambul, Pencere. 